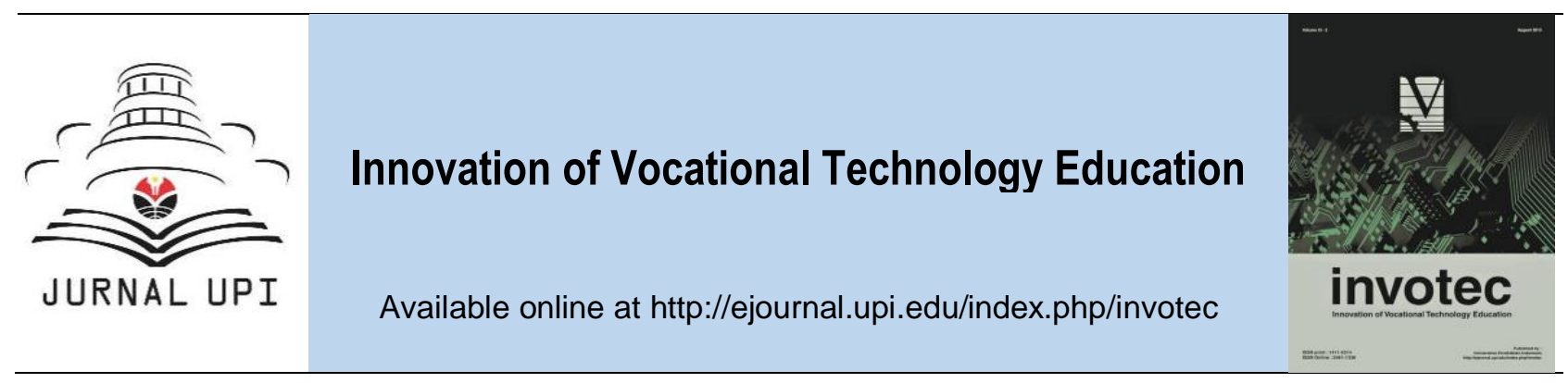

\title{
The Influence of Music and Learning Motivation to the Results of Learning the Productive Practice in Vocational High School Tourism Group
}

Elida

Universitas Negeri Padang, Indonesia

\section{ARTICLE INFO}

Article history:

Received 10 October 2017

Received in revised form 3 November

2017

Accepted 20 November 2017

Available online 28 February 2018

Keywords:

Music and learning motivation,

Productive practice,

Tourism group

Corresponding author:

elida@unp.ac.id

\section{A B S T R A C T}

The purpose of the research is to analyze difference of the results of students learning the practice of productive, that is: learning strategy between with music and without music, student who has high motivation even hard with learning process of with music and without music. Interactions between learning strategy with student learn motivation by music. This research is experiment research with factorial $2 \times 2$ designs. Population student $X$ grade Tata Boga major tourism group of vocational high school in West Sumatra. The sample is taken by multistage random sampling. The Data is analyzed descriptively and ANAVA two way analyzed and continued by Tukey test. The findings research shows that (1) the result of student learning the practice of productive group with learning music is higher than without learning music. (2) there is interaction between processes using music with student motivation learning that giving difference influence to the productive practice student learning (3) the result of group of students learning the practice of productive who have high motivation by learning music is higher than without learning music, and (4) The result of a group of students learning the practice of productive who have low motivation with learning music is lower than without music.

\section{Introduction}

Government has tried to developing world of education especially for Vocational High School, which related with rising of human competence like teacher certification, rising of process quality learning with classroom action researching, and operating kind of vocational education learning model such us individualized learning, mastery learning, cooperative learning, CTL, completing of 2004 curriculum or be called urriculum (curriculum base competence). Two years later, in 2006 be occurred education unit step curriculum and in 2007, government included innovative and fun element to implement CBC curriculum be acquainted with active, innovative, creative, effective and fun learning/ which be applied since basic education till high institution, the last become 2013 curriculum.

Concept and phenomenon which is described at above be expected able to rise quality and education grade along with competence of graduate vocational education, in the fact which appear is purpose of Vocational High School haven't materialized by satisfy. Tourism group of vocational 
high school as one of Vocational High School in West Sumatera has many problems, based first research that writer to do to some Tourism group of vocational high schools, found data that rising of students who didn't pass National Examination from year to year and didn't get job that is not appropriate, this envisage from data that is gained from some Vocational High Schools in West Sumatra to increase number of students who didn't pass national examination from year to year and from number graduation of last three year just 56,47\% worker, just $59,73 \%$ worker with suit skill, worker with un suits skill is $40,27 \%$, who didn't work is $24,61 \%$ and continuing study to High Institution is $19,67 \%$.

Phenomena indicate that learning process in Vocational High School experience inclination which contra productive hope the passage. Based on data shows $32 \%$ student has not fulfilled KKM value yet which is $71.54,89 \%$ has fulfilled value, however in the enough value and just 11 , $91 \%$ having good value of all category and nobody of student that having value very category. It have not satisfied yet the result of student in productive subject not only is caused by hard of the subject but also can be seen from several indications, from process though the result of study. From learning process sides can be seen, example student can be enjoying as one of fun activity, it means if certain learning is success less to increase the interest and motivation of student to learn, so that learning cannot be said effective. This concept make teacher be positioned as facilitator that able to directing participant in every learning process, were viewing this thing as revolution of learn where teacher is not only as knowledge source, but also as a prime actor who experience they are not as an information provider.

The practice of productive learning is subjects which have to be mastering the third domain and the implementation need more long time just than theory of learning, however can be made become more interesting to the student, if the teacher is using correct strategy that is strategy of fun learning. Based on the passage, have the four professional competences is the way of teacher be able to collect many potentials. Until learning become effective, one of that is ability of teacher to design and to apply strategy of fun learning, spirit of study appear when we are fun and study become affective if someone is getting happy while study (Caine and Caine, 1997).

Structuring of heart with music is the most activity which gets many opportunities that to create fun condition and to give spirit to practice of productive learning in workshop. Music can give influence to the teacher and student, a teacher can use music to organize emotional condition, change mental student and support environment of study, music helps student to work better and to memorize many ideas and music be stimulating, rejuvenate and strengthening learning, even in consciously or unconsciously, beside that so many students like music (DePoter, et. al.1999). The beat and harmony of music be able to influencing human physiologist especially brain waves and heart beat another to increasing memorize and feeling of music's be able to help student come in optimum of learning (Hudges, 1996; Hargreaves \& North, 1997).

Usage of classic music in learning process an teaching also give effect to the performance of teacher, handling the strained situation, and akward (Reigeluth, 1983; Lehman, et. al. 2007). The change boring condition become comfort and fun, able to become interactive, music able to give energy to the brain and make the brain become more relax and usage of classic music can facilitate students to be able to understand the material which is given by teacher to increase their result of student learning. This research is to analyze difference results of productive practice of learning between student who practice of productive learning which accompanied by music and without accompanied by music, between group of students who have high motivation to learn and low, Interaction between strategy of learning the practice of productive with motivation student to learn that's giving difference influence to the results of learning practice of productive of Vocation Basic Competence.

\section{Method}

This research is using experiment method with factorial $2 \times 2$ designs by randomized group design. The research will be implemented in 8 tourism group of state vocational high schools in west Sumatra. Target population the research is $10^{\text {th }}$ grade students kuliner program that following Vocational Basic Competence subject in 8 tourism group of State Vocational High Schools in West Sumatera there are 19 classes with the number of student is 422 students. The sample is taken by multi-stage random sampling is sample that taken step by step till get 6 classes of experiments and 6 classes of control which differences with high and low motivation. Collecting data to survey 
student motivation who using instrument like poll with Likert Scale that before has been tested the validity of reliability, and to survey the results of learning the practice will be used the format of assessment of the practice which made by the teacher who teach the subject. The testing of hypothesis research is using variants analyze technique (ANAVA) two ways with factorial 2x2 design. If testing of hypothesis significant it will be continued with Tukey test. Tukey test is used if it will be found interaction of two variables of using music and study motivation processed and analyzed data is using SPSS for Window 16.00

\section{Result and Discussion}

There are interaction and significantly principle influence between using music and learn motivation to analyze variants above this passage, so testing is continued with Tukey test between pair of data to choose average of groups which is higher than both of groups that be paired up.

Table 1. ANOVA two path learning outcomes practice product basic vocational subjects

\begin{tabular}{|c|c|c|c|c|c|c|c|}
\hline \multirow{2}{*}{ Variants } & \multirow{2}{*}{ JK } & \multirow{2}{*}{ dk } & \multirow{2}{*}{$\begin{array}{l}\mathrm{RJK}= \\
\mathrm{JK} / \mathrm{dk}\end{array}$} & \multirow{2}{*}{$\begin{array}{c}F_{h}= \\
\text { RJK/RJKD }\end{array}$} & \multicolumn{2}{|c|}{$F_{t}$} & \multirow{2}{*}{ Result } \\
\hline & & & & & $\alpha=0,05$ & $\alpha=0,01$ & \\
\hline Result of learning & 174.24 & 1 & 174.24 & $12.96^{*}$ & 3.96 & 6.96 & Sig \\
\hline Learn motivation & 64.00 & 1 & 64.00 & $4.76^{* *}$ & 3.96 & 6.96 & Sig \\
\hline Inter AB & 635.04 & 1 & 635.04 & $47.23^{*}$ & 3.96 & 6.96 & Sig \\
\hline Gallat & 1290.88 & 96 & 13.45 & - & - & - & \\
\hline Between Group & 873.28 & 3 & 291.09 & - & - & - & \\
\hline Total & 2164.16 & 99 & 21.86 & - & - & - & \\
\hline
\end{tabular}

Table 2. The results of Tukey Test between both of data groups

\begin{tabular}{lllll}
\hline \multirow{2}{*}{ Group } & \multirow{2}{*}{$\mathrm{n}$} & \multicolumn{1}{c}{$\mathrm{Q}_{\text {count }}$} & \multicolumn{1}{c}{$\mathrm{Q}_{\text {tabel }}$} & \\
& & \multicolumn{1}{c}{$\mathrm{A}_{1}=0,05$} & Result \\
\hline $\mathrm{A}_{1}-\mathrm{A}_{2}$ & 50 & $7,20^{* *}$ & 3,70 & Very Signicant \\
$\mathrm{B}_{1}-\mathrm{B}_{2}$ & 50 & $4,36^{*}$ & 3,70 & Significant \\
$\mathrm{A}_{1} \mathrm{~B}_{1}-\mathrm{A}_{2} \mathrm{~B}_{1}$ & 25 & $14,81^{\star *}$ & 3,79 & Very Signicant \\
$\mathrm{A}_{1} \mathrm{~B}_{2}-\mathrm{A}_{2} \mathrm{~B}_{2}$ & 25 & $4,63^{*}$ & 3,79 & Significant \\
\hline
\end{tabular}

The results of the test (Table 1 and 2), was from ANAVA calculation results above looked that value is $F_{\text {count }}=12,96>F_{\text {table }}=3,96$. It means that $H_{\circ}$ was rejected and $H_{1}$ was accepted, thus the hypothesis that said there are differences at the results of learning between student group that was given treatment with learning process with music and without music proved very significant. To see differences when giving treatment to be closer which learning that higher then continued with Tukey test, so it is gotten the value $Q_{\text {count }}=7,20>Q_{\text {table }}=3,70$. There are differences of results of learning the productive practice of Vocational Basic Competences student between process learning with music and without music, whereas student who was given treatment of process learning the productive practice accompanied by music have higher average $(82,04)$ than without using music $(79,40)$. So that hypothesis said the results of learning the productive practice of student group with learning accompanied by music is higher than without accompanied by music very significant.

The results of interaction testing is based on ANAVA counting, it looks that $F_{\text {count }}=47$, $23>F_{\text {table }}(0,01 ; 50)=6,96$. It means $H_{0}$ was rejected and $H_{1}$ was accepted, so the hypothesis that said interaction between strategies of learning the productive practice with student motivation learning was giving differences influence to the results of learning the productive practice of vocational basic competence very significant proved (Figure 1). 


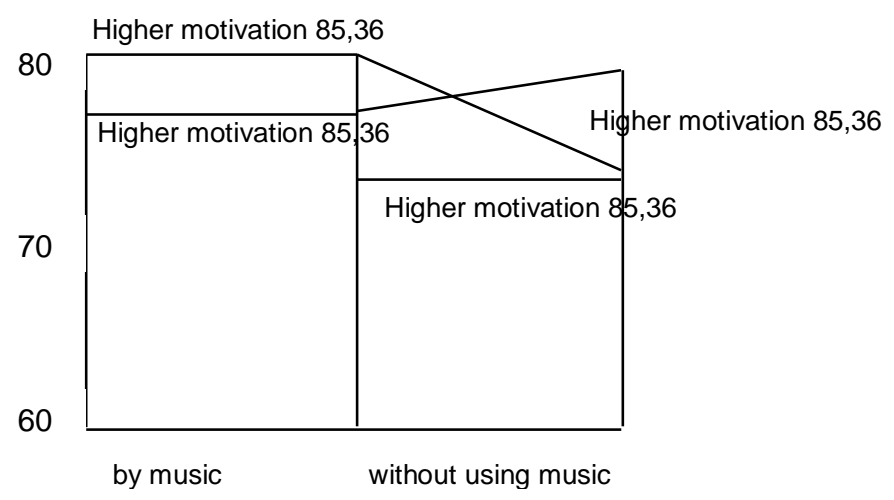

Figure 1. Interaction giving treatment of learning strategy with learns motivation to the result of learning the productive practice.

The Effectiveness of learning can be increased by many efforts. Fun Learning is one of many manners that can be done to get the effectiveness of learning. Learning is supported by conducive condition which giving to the increasing results of learning. Fun learning was learning where interaction between teacher and student, physical environment, and condition which giving change created conducive to learn (Romiszowski, 1981). The third factors were giving different impact to the happiness of learning depend on situation and condition in the class, so that election of strategy by teacher become important in increasing effectiveness of learning. Learning is supported by conducive condition which giving impact to the increasing results of learning, the situation is influenced too many factors like air circulation in the room, illumination, and influenced of music in learn situation. Using of music in the learning process that music at least used for (1) organize heart condition, (2) increasing results that be expected of learning, and (3) look at the important things. Heart situation is giving important influence to get accession results of learning (DePoter, et. at. 1999). Feel happy, comfort, and relax can open chance to the brain to work slowly. Thus, information which in get more access and to easier student to memorize because some part which attended with using certain music.

The process of learning the productive practice in workshop need to involve physical and mental and along time be started from practice preparation, implement practice, and pack up until make student become tired and bored. Student group who listened music when process of learning the productive practice on going feel different situation with group of students who are not using music, which class gets treatment learning with using music more relax and able to increase positive condition and happy. That why music very important to quantum learning, because music connected and influenced physiology, while do hard work, blood tension, and your heart beat lean to increase, brain waves to increase, and muscles become tight, with listening music relaxation and meditation, heart beat and blood tension to decrease, and muscles become loosen.

The interaction between treatment of strategy learning the productive practice with motivation learning to the results of learning the productive practice of students. The influence of interaction which showed by results of hypothesis testing, that using music in learning the productive practice of result of learning of student which the highest is student who have high motivation to learn. Also students who have low motivation to learn get result of learning the productive practice the highest on learning process without accompanied by music. This is showing that is interaction between strategy of learning the productive practice with student's motivation to learn. Interaction happened each factors in this research can be described which comparing characteristic of shape from strategy of learning which be given. When process of learning the productive practice accompanied by music will be very influenced to organize heart condition, heart condition is giving important influence to the results of learning. Happy, comfort, and relax can open opportunity to work easier, thus information which coming in get more access and clearly to make easier for memorizing of students because there are parts by using certain background of music.

In learn environment, researching shows that learn easier and faster if student in relax and receptive condition. Heartbeat of these people is 60 till 80 times per minutes (Roy, 2008). Using of music can be triggering and calming of self and change function of tight physical when body or mind getting suppressed, panic or tired body able to make cells of nerve in the brain be turn over till able to make someone can not thinking fresh and music able to help someone to thinking fresh 
and help body be relax, image language and beautiful music can arouse of learning, thinking, and arouse ability to handle a problem creatively (Ryan, 1980). Process of learning the productive practice in workshop involved physical and mental and more time which started from practice preparation, practice implementation and Packing up till make students be tired and bored. Group of students is played the music when process of learning the productive practice is on going feel different situation with group of students without using music. Class which given treatment of learning strategy with using music more relax and get increase heart which positive and cheerful condition. Thus interaction happened in this research is caused by different influenced from each type of learning strategy and learning motivation which student has.

Students who have high motivation which process of learning without using music, added with less serve of the facility, and also process of learning need long time and need physical to make the tired and bored because of the practice tasks, this is explained a general developing pattern results of learning. In this step, an upgrading which fast skill is called the discovery stage from learns (Parncutt and McPierson, 2007). The second group skill step where upgrading not too fast however stable enough. Next step study is called plateu, in this step just a little upgrading happened in a period. Followed pleateu symptoms is up down the irregularly achievements. Two last symptoms, plateu and up down the irregularly achievement is influenced by internal condition, like low motivation, exhausted chronic, less attention, and task concentration and also external factors like strategy of learning that used, divisions, distribution of training time or facility condition to learn and to exercise and also get source from student who try affluently, till occurring negative impact (overtraining).

Factor of internal and external condition influenced to the result of learning, (Clarke and Winch, 2007) especially to choose learning strategy, the Internal factor are personality developing, attitude making, learning strategy, growing level and developing, preparation also. Meanwhile according to Kokasih external factors is certain exercise. Exercise be able to do on; (1) train part of special duty, (2) coordinate parts of duty be a arrange performance that certain duty and time, (3) avoid moving duty, and (4) developing skill on the optimalization. For students who have low motivation of learning, when process of learning the productive practice accompanied by music, of course will feel unhappy, un comfort, and make spiritless working practice duty because they feel disturbed till can influence to their learning result. Otherwise student who have low motivation when working productive practice duty without music (Stipek, 1998), because they have usually with situation of the class which not using music they will feel happy with process of learning that usually have be used every productive practice.

\section{Conclusion}

There are result of learning the productive practice between group of students with process of learning with music and without music, whereas result of learning the productive practice which group of students with learning with music higher than group of students without using music. There is interaction strategy learning with learning motivation that giving different influenced to the result of learning productive practice. Result of learning the productive practice that has high motivation to learn with learning by music higher than without music. Results of learning the productive group of students that low motivation with learning accompanied by music lower than group of students without music.

\section{References}

Caine, R.N. \& Caine, G. 1997. Education the Edge of Possibility. Journal Association for Supervision and Curriculum Development Va: 159-160.

Clarke, L. \& Winch, C. (eds). 2007. Vocational Education. International Approachs, Developments and Systems. New York: Rout Colleage.

DePoter, B., Reardon, M. \& Nourie, S.S. 1999. Quantum Teaching Mempraktikkan Quantum Learning di Ruang-Ruang Kelas .Terjemahan oleh Ari Nilandari. 2010. Bandung: Kaifa. 
Hargreaves, D.J. \& North, A.C. (eds). 1997. The Social Psychology of Music. New York: Oxford University Press.

Hudges, D.A. (ed.). 1996. Handbook of Music Psychology. San Antonio Texas: LMR Press.

Lehmann, A., Sloboda, J.A. \& Woody, R.H. 2007. Psychology for Musician. New York: Oxford University Press.

Parncutt, R. \& McPierson, G.E. 2007. The Science and Psychology of Music Performance. New York: Oxford University Press.

Reigeluth, C.M. 1983. Instructional Design Theories and Model. New Jersey: Lawrence Erlbaum Associates Publisher.

Romiszowski, A.J. 1981. Designing Instructional System. London: Kogen Page.

Roy, S. 2008. The Effects of Different Types of Music on Cognitive Processes. Department of Nose. (D: /afifa/my document/jurnal music/the effects of different types of music on cognitive proceses.mnt) diakses October 2008.

Ryan, D.C. 1980. Characteristics of teacher. A Research study: Their description, comparation, and appraisal. Washington, DC: American Council of Education.

Stipek, D. 1998. Motivation to Learn. From Theory to Practice. Boston: Allyn and Bacon. 